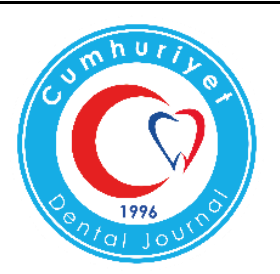

\title{
COMPARATIVE ANALYSIS OF MANUAL, ROTARY, AND RECIPROCAL SYSTEMS ON PRIMARY TEETH ROOT CANALS: AN IN VITRO SCANNING ELECTRON MICROSCOPY STUDY
}

\begin{abstract}
Objective: To evaluate the residual debris and smear layer formation, and also preparation time of one or multifile manual, rotary, and reciprocal systems on primary teeth.
\end{abstract}

Materials and methods: A total of 75 primary mandibular molar teeth were randomly divided to five groups $(n=15)$. The distal canals of teeth were shaped with each of the K file, Protaper, Twisted File, OneShape, and Reciproc systems. Preparation time was also recorded. Longitudinal sections groups were prepared and processed for observation under scanning electron microscopy (SEM) at a standard magnification of X1000 for smear layer and X200 for residual debris. The presence of smear layer and residual debris was evaluated by two trained operators. The data of preparation time and also debris and smear scores were analyzed using ANOVA and the Kruskal-Wallis test, respectively.

Results: Reciproc and OneShape systems had significantly less instrumentation time than all other groups $(\mathrm{p}<0.001)$. The results of statistical analyses were the same for the residual debris and smear layer scores. In the coronal thirds of the canals, the canal preparation with the Protaper system resulted in significantly less debris and smear layer compared with the OneShape system $(\mathrm{p}=0.015)$. In the middle thirds of the canals, OneShape and Reciproc systems had more residual debris and smear layer than the Protaper system $(p<0.05)$. In the apical thirds of the canals, the use of the Protaper instruments resulted in less debris and smear layer than the Reciproc system $(\mathrm{p}=0.034)$.

Conclusions: Within the limits of this study, the Protaper system, which showed better cleaning efficacy and was also faster than the manual system, can be an effective alternative to other systems in the root canal treatment of primary molars. More in vitro and clinical investigations are needed on root canal treatment of primary teeth.

Keywords: Primary teeth, root canal therapy, smear layer, microscopy, scanning.

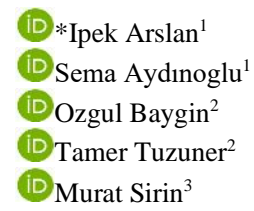

ORCID IDs of the authors: I.A. 0000-0002-8648-3554 S.A. 0000-0003-1490-8645 O.B. $0000-0003-2220-7654$ T.T. 0000-0001-5817-5928 M.S. 0000-0001-6864-752X

\footnotetext{
Department of Pediatric Dentistry, Faculty of Dentistry, Recep Tayyip Erdoğan University, Rize, Turkey.

2 Department of Pediatric Dentistry, Faculty of Dentistry, Karadeniz Technical University, Trabzon, Turkey.

${ }^{3}$ Department of Physics, Faculty of Arts and Science, Recep Tayyip Erdoğan University, Rize, Turkey.
}

How to Cite: Arslan İ, Aydınoglu S, Baygin Ö, Tuzuner Ö, Sirin M. Comparative Analysis of Manual, Rotary and Reciprocal Systems on Primary Teeth Root Canals: An In Vitro Scanning Electron Microscopy Study. Cumhuriyet Dent J 2019;22:3:299-309.

*Corresponding Author:

Department of Pediatric Dentistry, Faculty of Dentistry, Recep Tayyip Erdoğan University, Rize, Turkey.

Phone: +90 5379588487 Fax: +90 4642220002 E-mail: sareipekarslan@gmail.com 


\section{INTRODUCTION}

The preservation of primary teeth until they are replaced by their successor is one of the most important missions of pediatric dentistry. ${ }^{1}$ Early loss of the primary teeth can cause malocclusion, and masticatory, aesthetic, and speech problems. Therefore, to prevent these complications, root canal treatment of primary teeth has gained importance. $^{2}$ On the other hand, root canal treatment of primary teeth has some difficulties when compared with permanent teeth due to the anatomic and morphologic differences between them and the behavioral management problems of children. ${ }^{3}$ For these reasons, chair time of pulpectomy in primary teeth should be as short as possible. ${ }^{4}$

Traditionally, stainless steel files have been used in the root canal treatment of primary root canals. However, stainless steel files have some limitations such as increased preparation time and imbalanced preparation of the root canal space. ${ }^{4}$ To overcome these disadvantages, engine-driven NiTi instruments were introduced to pediatric dentistry by Barr et al. ${ }^{5}$ Engine-driven NiTi files have shape memory and high elasticity so they easily follow the original anatomy of the root canal then produce conical-shaped canal preparation, and also reduce the preparation time. ${ }^{5,6}$

To date, many NiTi endodontic file systems have been produced by different manufacturers. Many of them recommend the use of multi-file concepts to shape the root canals. In the present study, the Protaper and Twisted file multi-files systems were used.

ProTaper (Dentsply Maillefer, Ballaigues, Switzerland) has been widely recommended and is one of the frequently used multi-file rotary systems (Mtwo-Twisted file). It has eight instruments; three for shaping (SX, S1 and S2) and the others for finishing. The files have an increasing taper design and a triangular, convex cross-section. This design provides high cutting efficiency. ${ }^{7}$

Twisted File (SybronEndo, Orange, CA, USA), which is another multi-file rotary system, is produced via twisting the metal in combination with R-phase heat treatment to advance super-elasticity. ${ }^{8}$
A triangular cross-section and constant tapers as $0.04,0.06,0.08,0.10$, and 0.12 are seen in Twisted Files. They also have 5 tip sizes (25-50). ${ }^{9}$

New concepts of the engine-driven NiTi file systems called single-files have simplified the instrumentation protocol. ${ }^{10}$ Single-file systems have several advantages including reduced working time, crosscontamination prevention, and improved safety of the shaping procedures. ${ }^{11,12}$ The two different motions of single-file systems are continuous rotation and reciprocation. ${ }^{10}$

OneShape (OS; Micro Méga, Besançon, France) was the first single-file continuous rotation endodontic system made of conventional austenite 55-NiTi alloy. ${ }^{13}$ Only one instrument is found in the system. It has a constant $6 \%$ taper and a noncutting tip of size 25 . To prevent a screwing effect, the variable design includes a S-shaped triangular cross-section. ${ }^{14}$

The reciprocating motion has a counterclockwise rotation for cutting the dentin and shorter clockwise rotation to prevent the file from locking into the canal wall. ${ }^{8}$ Thus, increased cyclic fatigue life and torsional resistance of NiTi instruments are provided with the reciprocating motion compared with the rotary motion. ${ }^{15,16}$ However, less debris accumulation was reported with rotary motion. ${ }^{17}$

Reciproc (VDW GmbH, Munich, Germany) is the single-file endodontic system that has a specialized motor that provides clockwise and counter clockwise motion. ${ }^{18}$ Reciprocal motion in a $150^{\circ}$ counter-clockwise (cutting direction) and $30^{\circ}$ clockwise (release of the instrument) rotation and performs balanced force, which is reliable for curved canals. ${ }^{19}$ Reciproc files are made of heattreated M-wire nickel-titanium alloy that is resistant to fatigue. ${ }^{20}$

Debris and smear layer are produced by root canal instruments during shaping protocols. ${ }^{21}$ These formations may create a reservoir area for bacteria and their products may also reduce the adaptation of sealer and gutta-percha. ${ }^{22}$ Little information is available about the debris and smear layer in primary teeth, contrary to permanent teeth. ${ }^{6}$ 
The aim of this study was to compare the formation of debris and smear layer and preparation time of K File, Protaper Universal, Twisted File, OneShape, and Reciproc systems on primary teeth.

\section{MATERIALS AND METHODS}

A total of 75 human primary mandibular molar teeth that were extracted for various reasons were collected from the department of pediatric dentistry. Ethical approval was obtained from the Ethics Committee of Karadeniz Technical University, Faculty of Medicine (Protocol \# 2016$63)$. The teeth were virgin without any treatment. The inclusion criteria were absence of external or internal pathologic root resorption, absence of perforation in the internal or external furcation area, moderate root angulation, ${ }^{23}$ and two-thirds of an intact root. All the teeth were radiographically evaluated to analyze root canal anatomy. The teeth were cleaned ultrasonically and stored in $1 \% \mathrm{~T}$ Chloramine solution (Merck, Darmstadt, Germany) until use.

An ideal access cavity was prepared for each tooth to obtain straight-line access to the root canal. The crown of each tooth was removed and the roots of the teeth were divided using a bur. Distal roots, which were standardized to $15-\mathrm{mm}$ length, were selected for shaping. Two longitudinal grooves were prepared on the buccal and lingual surfaces of each root with a diamond bur with the aim of facilitating vertical splitting for SEM evaluation after the canal instrumentation. The roots were divided into 5 groups. Working length determination was done by measuring \#10 K-file visible at the apical foramen minus $1 \mathrm{~mm}$. All root canals were shaped by a single operator as follows:

K-file group: Root canals were shaped manually with K-files (Dentsply Maillefer, Ballaigues, Switzerland) up to the ISO file size 25 to the working length.

Protaper group: ProTaper instruments (Dentsply Maillefer, Ballaigues, Switzerland) were used in a modified crown down technique according to the manufacturer's instructions with a gentle in-andout motion, with attention paid to applying light apical pressure. The shaping of the root canal orifice was performed with SX instruments at twothirds of the working length. S1 and S2 shaping files were used, followed by finishing files F1 and F2 (25/0.08) with continuous rotation motion.

Twisted file group: Twisted file instruments were used in a modified crown down technique according to the manufacturer's instructions with gentle in-and-out motion, also paying attention to applying light apical pressure. A size 25/0.08 file was used in a passive manner $2 \mathrm{~mm}$ short of the working length. Afterwards, a 25/0.06 file was used with continuous rotation motion at the working length.

OneShape group: OneShape instruments (MicroMega, Besancon, France) were used according to the manufacturer's instructions with a gentle in-and-out motion applying light apical pressure. A size 25/0.06 file was used with a continuous rotation motion at the working length.

Reciproc group: Reciprocal instruments were used according to the manufacturer's instructions with a gentle in-and-out motion with light apical pressure. A size 25/0.08 file was used with reciprocating motion at the working length.

The root canals were irrigated between each instrument with $2 \mathrm{~mL}$ of $2.5 \%$ sodium hypochlorite solution via 27 gauge needles.

The total preparation time for each canal included the time required for active instrumentation, cleaning and changing the instruments, and irrigation was recorded.

After the preparation time recorded standard irrigation regimens with $4 \mathrm{~mL}$ of $17 \%$ EDTA (Saver, Prime Dental Products, India) for 120 seconds followed by $1 \mathrm{~mL}$ of $2.5 \%$ sodium hypochlorite for 60 seconds. At the end, $1 \mathrm{~mL}$ of ethanol for 30 seconds was used as a final rinse and the canals were dried with calibrated paper points (Absorbent Paper Points, Dentsply-Maillefer, Konstanz, Germany).

Each sample was dipped in liquid nitrogen after the instrumentation to split them into two halves longitudinally using a stainless steel chisel. The sections were then allowed to air-dry overnight at room temperature, sputter-coated with gold 
(SC7620 “Mini”, Polaron Sputter Coater, Quorum Technologies, Newhaven, England), and prepared for scanning electron microscope (SEM) analysis (JSM-6610; JEOL, Peabody, Massachusetts, USA). One part was chosen for the assessment of residual debris and smear layer.

To standardize the examined area for each sample, the technique previously applied by Gorduysus et al. ${ }^{24}$ was used. According to this technique, the central beam of the SEM was directed to the center of the specimen under X10 magnification, and the magnification was increased to X200 for debris evaluation, and then to X1000 for smear layer evaluation in coronal, middle, and apical thirds of the roots.

Dentin chips, pulpal remnants, and other particles loosely stuck to the canal wall were accepted as debris as previously defined by Hulsmann ${ }^{17}$ and scored with the criteria described by the same author ${ }^{25}$ as follows:

Score 1: Clean root canal wall, only a few small debris particles.

Score 2: Few small agglomerations of debris.

Score 3: Many agglomerations of debris covering less than $50 \%$ of the root canal wall.

Score 4: More than $50 \%$ of the root canal wall covered by debris.

Score 5: Complete or nearly complete root canal wall covered by debris.

A surface film retained on dentin and other surfaces after instrumentation with either rotary instruments or endodontic files was accepted as 'smear layer' like previously defined by American Association of Endodontists ${ }^{26}$ and scored with the criteria described by Hulsmann et al. ${ }^{25}$ as follows;

Score 1: No smear layer, dentinal tubules open.

Score 2: Small amount of smear layer, some open dentinal tubules.

Score 3: Homogenous smear layer covering the root canal wall, only a few open dentinal tubules.

Score 4: Complete root canal wall covered by a homogenous smear layer, no open dentinal tubules.
Score 5: Heavy, homogenous smear layer covering the entire root canal wall.

A total of 450 images ( 75 samples $X 3$ region; coronal, middle and apical X2 for debris and smear) were analyzed twice at an interval of 8 weeks by two blinded and experienced observers (Kappa: 0.76). When differences occurred in the scoring of the images, the two observers rescored the images and discussed them until reaching a consensus.

Statistical analysis was performed using the Stata 12.0 software (Stata, College Station, Texas, USA). Descriptive statistics for ordinal data, including the median, minimum and maximum values were calculated for all groups. The preparation time data were analyzed with a parametric test of one-way analysis of variance (ANOVA) and Tamhane was performed for groupwise comparison. Debris and smear scores were analyzed with the non-parametric Kruskal-Wallis test and the Mann-Whitney U test was performed in group-wise comparisons. The significance of all statistical tests was predetermined at $\mathrm{p}<0.05$.

\section{RESULTS \\ Preparation Time}

The mean time taken to prepare the canals for the different file systems is shown in Table 1. Reciproc and OneShape systems, which are single-file systems, had significantly less preparation time than all other groups $(p<0.001)$. There were no statistically significant differences between these single-file systems $(\mathrm{p}=0.85)$. The slowest system was the K-File $(\mathrm{p}<0.001)$, and the Twisted file system had a shorter preparation time than the ProTaper system $(p<0.001)$ and longer preparation time than single-file systems $(\mathrm{p}<0.001)$. The ProTaper system had a shorter preparation time than manual systems and longer preparation times than Twisted File and single-file systems $(\mathrm{p}<0.001)$. 
Aslan I, et al.

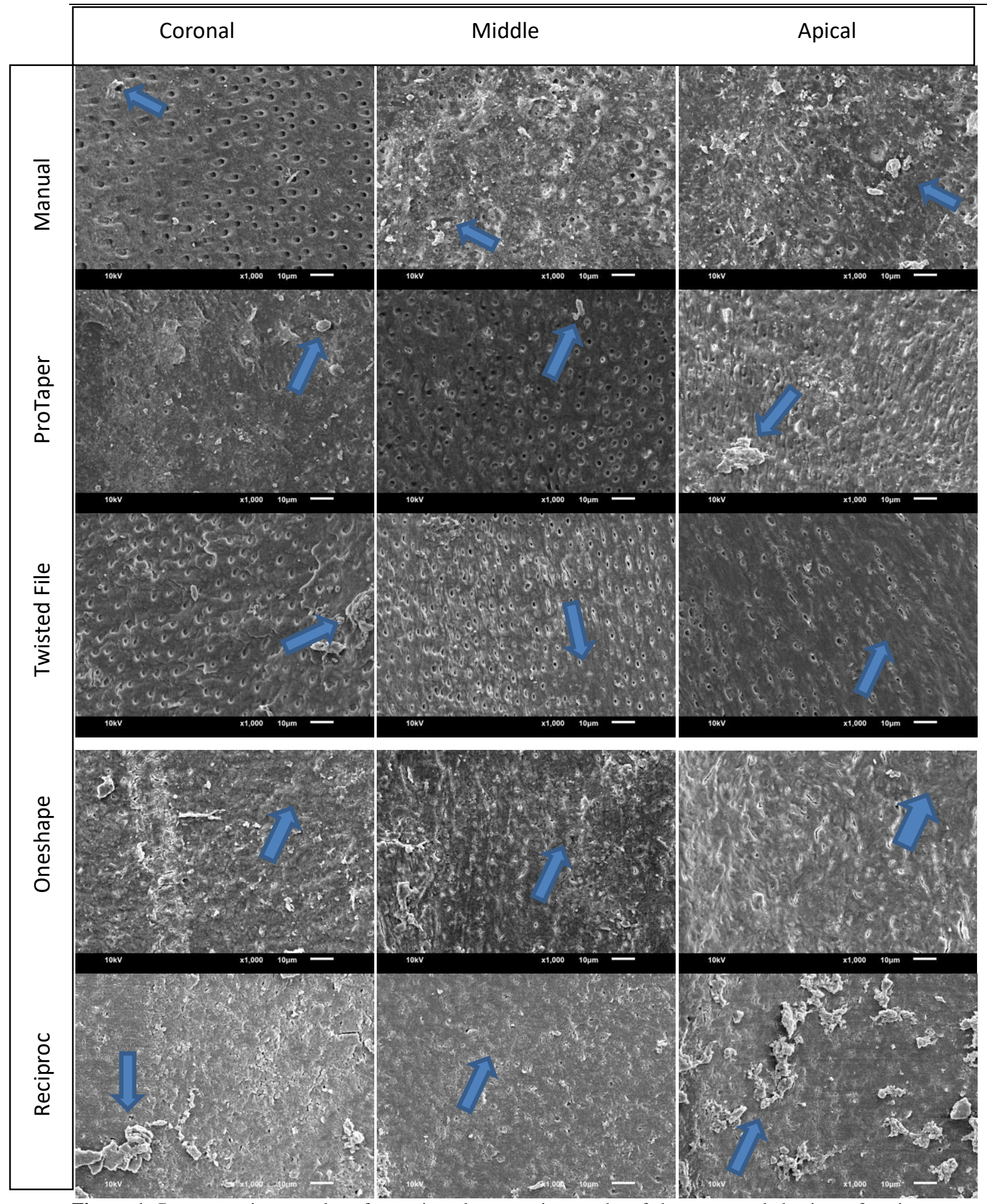

Figure 1. Representative samples of scanning electron micrographs of the root canal dentin surface instrumented with Manual, ProTaper, Twisted file, OneShape, and Reciproc systems at the coronal, middle, and apical third of the root (X1000). 


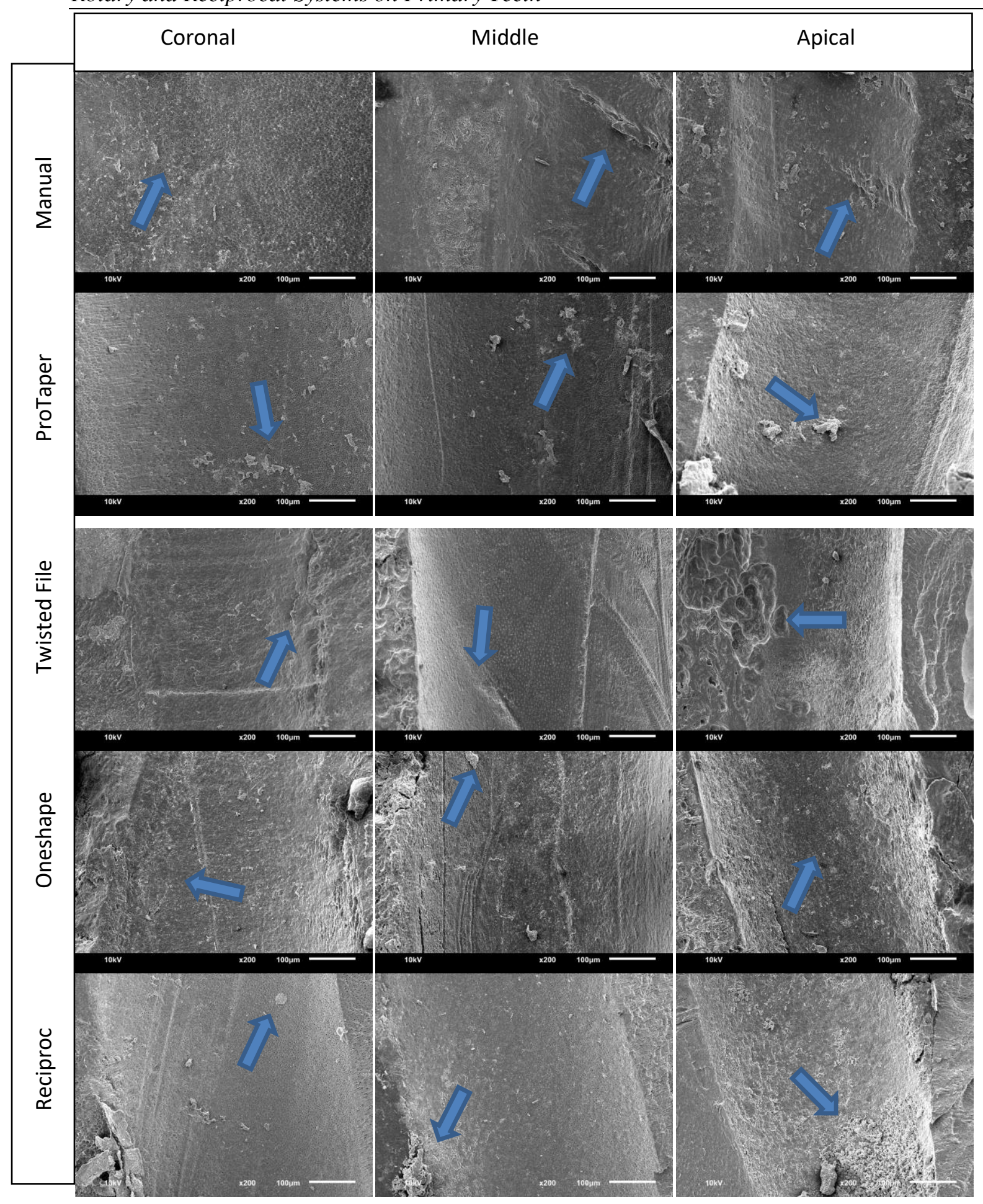

Figure 2. Representative samples of scanning electron micrographs of the root canal dentin surface instrumented with Manual, ProTaper, Twisted file, OneShape, and Reciproc systems at the coronal, middle, and apical third of the root (X200). 
Table 1. Mean preparation time in seconds and standard deviation (SD) in different groups.

\begin{tabular}{ccc}
\hline & Mean & SD \\
\hline Manual & $246,26^{\mathrm{a}}$ & 72,34 \\
ProTaper & $128,53^{\mathrm{b}}$ & 13,21 \\
Twisted File & $71,8^{\mathrm{c}}$ & 10,28 \\
OneShape & $13,2^{\mathrm{d}}$ & 6,31 \\
Resiproc & $22,33^{\mathrm{d}}$ & 10,61
\end{tabular}

Values with the different superscript letters showed statistically different groups $(\mathrm{p}<0.001)$.

\section{Debris and Smear Layer Scores}

The debris and smear layer scores are summarized in Table 2 and 3. No completely cleaned root canals were found in any groups. The results of statistical analyses were the same for the scores of residual debris and smear layers. In the coronal thirds of the canals, the canal preparation with ProTaper systems resulted in significantly less debris and smear layer compared with the OneShape instrument $(\mathrm{p}<0.05)$. In the middle thirds of the canals, OneShape and Reciproc systems showed more residual debris and smear layer than the Protaper system $(\mathrm{p}<0.05)$. Also, the K-file group showed less debris and smear scores than the OneShape group in the middle thirds. In the apical thirds of the canals, ProTaper instruments resulted in less debris and smear layer than Reciproc systems $(\mathrm{p}=0.034)$

Table 2. Median, minimum (MIN), and maximum (MAX) scores of smear layer and residual debris at the coronal, middle and apical area.

\begin{tabular}{cccccccc}
\hline & \multicolumn{4}{c}{$\begin{array}{c}\text { SMEAR LAYER } \\
\text { Median (MIN-MAX) }\end{array}$} & \multicolumn{3}{c}{$\begin{array}{c}\text { RESIDUAL DEBRIS } \\
\text { Median (MIN-MAX) }\end{array}$} \\
\hline Groups & N & Coronal & Middle & Apical & Coronal & Middle & Apical \\
Manual & 15 & $1(1-4)$ & $2(1-4)$ & $3(2-4)$ & $1(1-4)$ & $2(1-4)$ & $3(2-4)$ \\
ProTaper & 15 & $1(1-3)$ & $2(1-3)$ & $3(1-4)$ & $1(1-3)$ & $2(1-3)$ & $3(1-4)$ \\
Twisted File & 15 & $1(1-3)$ & $2(1-3)$ & $3(2-5)$ & $1(1-4)$ & $2(1-4)$ & $3(1-5)$ \\
One shape & 15 & $3(1-4)$ & $3(1-4)$ & $3(1-5)$ & $3(1-5)$ & $3(1-5)$ & $3(1-5)$ \\
Reciproc & 15 & $2(1-4)$ & $3(1-4)$ & $3(2-4)$ & $2(1-4)$ & $3(1-4)$ & $3(2-5)$ \\
\hline
\end{tabular}

Table 3. Comparison of the endodontic systems used in the study with respect to the area.

\begin{tabular}{|c|c|c|c|c|c|c|}
\hline \multicolumn{7}{|c|}{ Groups (p value) } \\
\hline & & Manual & ProTaper & Twisted File & OneShape & Reciproc \\
\hline \multirow[t]{3}{*}{ Area } & Groups & & & & & \\
\hline & Manual & - & 1.00 & 1.00 & 0.226 & 1.00 \\
\hline & ProTaper & 1.00 & - & 1.00 & $\underline{0.015^{*}}$ & 0.689 \\
\hline \multirow[t]{5}{*}{ Coronal } & Twisted File & 1.00 & 1.00 & - & $\overline{0.258}$ & 1.00 \\
\hline & OneShape & 0.226 & $\underline{0.015}{ }^{*}$ & 0.258 & - & 1.00 \\
\hline & Reciproc & 1.00 & $\overline{0.689}$ & 1.00 & 1.00 & - \\
\hline & Manual & - & 1.00 & 1.00 & $\underline{0.042}{ }^{*}$ & 0.204 \\
\hline & ProTaper & 1.00 & - & 0.581 & $0.007^{*}$ & $\underline{0.042^{*}}$ \\
\hline \multirow[t]{5}{*}{ Middle } & Twisted File & 1.00 & 0.581 & - & 1.00 & $\overline{1.00}$ \\
\hline & OneShape & $\underline{0.042^{*}}$ & $\underline{0.007^{*}}$ & 1.00 & - & 1.00 \\
\hline & Reciproc & $\overline{0.204}$ & $\underline{0.042^{*}}$ & 1.00 & 1.00 & - \\
\hline & Manual & - & $\overline{1.00}$ & 1.00 & 1.00 & 0.204 \\
\hline & ProTaper & 1.00 & - & 1.00 & 0.284 & $\underline{0.034}{ }^{*}$ \\
\hline \multirow[t]{3}{*}{ Apical } & Twisted File & 1.00 & 1.00 & - & 1.00 & $\overline{0.508}$ \\
\hline & OneShape & 1.00 & 0.284 & 1.00 & - & 1.00 \\
\hline & Reciproc & 1.00 & 0.034* & 0.508 & 1.00 & - \\
\hline
\end{tabular}

\footnotetext{
: Statistically significant differences $(\mathrm{p}<0.05)$
} 


\section{DISCUSSION}

Root canal treatment is a complex procedure comprising removal of pulp tissue, residual necrotic materials, debris, and infected dentin, and also sealing the canals with biocompatible materials. ${ }^{27}$ The geometric anatomy of primary tooth pulp is more complicated than in permanent teeth because of the greater numbers of accessory canals, lateral canals, fins, anastomoses between canals and apical delta, and short and thin roots. ${ }^{28}$ In addition to anatomic problems, behavioral management of children makes root canal treatment of primary teeth more difficult. ${ }^{3}$ For these reasons, completing the root canal procedure in a shorter time and providing good quality treatment are desirable choices for pediatric practitioners. ${ }^{27}$

Engine driven NiTi systems were introduced to pediatric dentistry in order to reduce chair time and produce a more uniform and funnel-shaped preparation through their high elasticity and timeconsuming nature. ${ }^{5,6}$ Nevertheless, there are limited published data about primary teeth root canal treatment with engine driven NiTi systems. ${ }^{4,5,27,29}$ In the present study, manual, rotary, and reciprocal NiTi systems were evaluated for preparation time, residual debris, and smear layers in primary teeth.

Preparation time is an important factor to draw conclusions on the efficacy of endodontic systems and on their clinical suitability. ${ }^{30}$ In the present study, the preparation times of K-file-multifile manual systems, ProTaper and Twisted Filemultifile rotary systems, OneShape-single file rotary systems, and Reciproc-single file reciprocal systems were investigated. Preparation time included active instrumentation time and the time required for irrigation, changing the file, and cleaning the flutes as in previous studies. ${ }^{17,31}$

The K-file-multifile manual group was significantly slower than all of the engine-driven groups $(p<0.001)$, in agreement with previous studies. ${ }^{29,32}$ In the present study, ProTaper, Twisted File, OneShape, and Reciproc groups consisted of 4, 2, 1 and 1 files, to prepare the root canal to a size of 25 , respectively. As expected, preparation time increased with increasing file numbers $(p<0.001)$.
No significant difference was found between the OneShape and Reciproc groups, both of which were single-file systems $(\mathrm{p}=0.85)$, contrary to the study of Saber et al. ${ }^{33}$ This status might be due to the extremely curved permanent teeth that were used in the previous study, controversy to the present study. Also, Saber et al. declared that from a clinical point of view, the differences between these instruments might be of no importance. ${ }^{33}$

One of the most important objectives of root canal preparation is the removal of vital and/or necrotic pulp tissue, infected dentin, and dentin debris to eliminate most of the microorganisms from the root canal system. ${ }^{34}$ In the present study, manual, rotary, and reciprocal systems were evaluated to achieve these objectives by analyzing residual debris and smear layer removal via SEM photomicrographs.

The magnification 200X, which offered a wider view, was used for residual debris evaluation, and the magnification 1000X, which gave detailed information, was used for smear layer evaluations.

The ProTaper system had significantly better results than the OneShape system $(p<0.05)$. ProTaper has multi-file system and with the multifile technique canals are irrigated more frequently because irrigation regimen is used with every file change so debris will have less opportunity to accumulate in canals. ${ }^{35}$ Other multifile systems also showed better results than OneShape but not statistically different. This result is in accordance with the previous study of Kansal et al. ${ }^{35}$ Also, the taper sizes of the ProTaper and OneShape are 0.08 and 0.06 , respectively. The increase of taper may cause large preparation, which allows a larger volume of irrigants to be in contact with canal walls. ${ }^{36}$ The better results of ProTaper may be attributed to these factors.

In this study, the multi-file systems (ProTaper, Twisted File, and K-file) were not statistically different according to the residual debris and smear layer scores $(p>0.50)$. This finding is consistent with the previous studies. ${ }^{37,38}$ Celik et al. ${ }^{37}$ compared the cleaning effectiveness of Twisted File, GT series X, Revo-S, RaCe, Mtwo, and 
ProTaper Universal rotary files in curved canals. No statistically significant differences were found between the groups in terms of debris scores and smear layer scores, in agreement with the present study. Li et al. ${ }^{39}$ evaluated the cleaning efficiency of Twisted File and ProTaper rotary instruments. The results of this study are not in agreement with the present study in the coronal area. The probable reasons for the disparity could be the differences between the methods. They used permanent molars, and in the present study, deciduous molars were used.

Reciproc had worse cleaning efficacy results than ProTaper $(\mathrm{p}<0.05)$. The continuous rotation motion provides an exit for debris up to the flutes of the file. By contrast, with the reciprocal motion, each backward motion of the file pushes debris into the lateral canals and over the apex. ${ }^{40}$ Robinson $e t$ $a l .{ }^{40}$ also showed that ProTaper had better cleaning efficacy than Waveone, which is a reciprocal system. Although Twisted file and OneShape are continuous rotation systems, they did not show any statistically significant difference $(p>0.05)$. This can be because of the taper differences. The taper of Reciproc, Twisted file, and OneShape are 0.08, 0.06 , and 0.06 , respectively. Despite the reciprocal motion, the greater taper size of Reciproc may have caused the similar results as the Twisted File and OneShape systems.

The limitations of the present study are that SEM images present two-dimensional investigations, whereas three-dimensional methods allow to evaluate root canal anatomy in detail and reflect the clinical conditions more realistically. Also, in vivo studies with more samples are needed.

\section{CONCLUSIONS}

Within the limits of this study, all of the engine driven NiTi systems were preferable to manual systems when the chair time was taken into account. These systems may be preferable for the root canal treatments of children who have cooperation problems. However, based on the results of the present study, ProTaper systems, which showed better cleaning efficacy and shorter preparation time than manual systems, can be an effective alternative to other systems on the root canal treatment of primary molars. Nonetheless, more investigations are needed on root canal treatment of primary teeth, which are anatomically and morphologically different from the permanent teeth.

\section{ACKNOWLEDGEMENTS}

None

\section{CONFLICT OF INTEREST STATEMENT}

None

Süt Dişi Kök Kanal Şekillendirilmesinde Manuel, Döner ve Resiprokal Sistemlerin Karşılaştırmalı

Olarak Incelenmesi; In Vitro Taramalı Elektron Mikroskobu Çalışması

$\ddot{O} Z$

Amaç: Manuel, rotary ve resiprokal sistemlerin süt dişi kök kanallarında kullanımınin debris ve smear tabakası oluşumuna ayrica preperasyon süresine etkilerinin incelenmesidir. Gereç ve Yöntemler: Toplamda 75 adet süt mandibular molar diş 5 gruba ayrld l (n:15). Dişlerin distal kanalları K tipi ĕge, Protaper, Twisted File, OneShape and Reciproc sistemlerinden biri ile şekillendirildi. Ayrıca preperasyon zamanı da ölçüldü. Taramal elektron mikroskopu (SEM) değerlendirilmesi için dişler uzunlamasina ikiye bölündü. Smear tabakasinin değerlendirilmesi için 1000, debris için 200 büyütmede inceleme 2 deneyimli hekim tarafindan yapıldl. Preparasyon süresi için ANOVA, Smear tabakası ve debris değerlendirilmesi için Krukal Wallis testleri uyguland. Bulgular: Reciproc ve OneShape sistemleri diğer gruplara göre istatistiksel olarak anlaml derecede daha kisa preperasyon zamanina sahipti $(p<0,001)$. Istatitiksel analiz bulgulart debris ve smear tabakast aynlydl. Koronal bölgede Protaper grubu OneShape grubuna göre daha az debris ve smear tabakası gösterdi $(p<0,05)$. Orta bölgede OneShape ve Reciproc gruplarında Protaper grubuna göre daha fazla debris ve smear tabakası gözlendi $(p<0,05)$. Apikal bölgede Protaper grubu OneShape grubuna göre daha az debris ve smear tabakası sergiledi $(p<0,05)$. Sonuçlar: Bu çalı̧̧manin sinırları göz önünde bulundurularak Manuel sisteme göre daha hizll ve temizleme etkinliği diğer sistemlerden daha yüksek olan Protaper sistemi süt dişi kök kanal şekillendirilmesinde etkin bir alternatifolabilir. Süt dişlerinin kök kanal tedavileri ile ilgili daha fazla in vitro ve klinik çalışmalara ihtiyaç duyulmaktadır. Anahtar kelimeler: Süt dişi, kök kanal tedavisi, smear tabakası, mikroskobi, tarama. 


\section{REFERENCES}

1. Park K, Jung DW, Kim JY. Three-dimensional space changes after premature loss of a maxillary primary first molar. Int J Paediatr Dent 2009;19:383-389.

2. Sevekar SA, Gowda SHN. Postoperative Pain and Flare-Ups: Comparison of Incidence Between Single and Multiple Visit Pulpectomy in Primary Molars. J Clin Diagn Res 2017;11:ZC09-ZC12.

3. Dean J AD, McDonald RE. Dentistry for the Child and Adolescent. In: Dean J AD. Treatment of Deep Caries, Vital Pulp Exposure and Pulpless teeth Mosby. Elsevier St. Louis 2010:343-366.

4. Silva LA, Leonardo MR, Nelson-Filho P, Tanomaru JM. Comparison of rotary and manual instrumentation techniques on cleaning capacity and instrumentation time in deciduous molars. J Dent Child (Chic) 2004;71:45-47.

5. Barr ES, Kleier DJ, Barr NV. Use of nickel-titanium rotary files for root canal preparation in primary teeth. Pediatr Dent 2000;22:77-78.

6. Pinheiro SL, Araujo G, Bincelli I, Cunha R, Bueno C. Evaluation of cleaning capacity and instrumentation time of manual, hybrid and rotary instrumentation techniques in primary molars. Int Endod J 2012;45:379-385.

7. Garg S, Mahajan $\mathrm{P}$, Thaman $\mathrm{D}$, Monga $\mathrm{P}$. Comparison of dentinal damage induced by different nickel-titanium rotary instruments during canal preparation: An in vitro study. J Conserv Dent 2015;18:302-305.

8. Yılmaz K, Özyürek T. Apically Extruded Debris after Re-treatment Procedure with Reciproc, ProTaper Next and TF Adaptive Instruments. J Endod 2016;43:648-651.

9. $\mathrm{Wu} X C, \mathrm{Zhu} Y \mathrm{Y}$. Geometric analysis of root canals prepared by single twisted file in three different operation modes. Eur J Dent 2014;8:515-520.

10. Agarwal RS, Agarwal J, Jain P, Chandra A. Comparative Analysis of Canal Centering Ability of Different Single File Systems Using Cone Beam Computed Tomography- An In-Vitro Study. J Clin Diagn Res 2015;9:ZC06-ZC10.

11. Shay B, Moshonov J. Single file endodontic treatment: a new era? Refuat Hapeh Vehashinayim (1993) 2013;30:6-9.

12. Prabhakar AR, Yavagal C, Dixit K, Naik SV. Reciprocating vs Rotary Instrumentation in Pediatric Endodontics: Cone Beam Computed Tomographic
Analysis of Deciduous Root Canals using Two Singlefile Systems. Int J Clin Pediatr Dent 2016;9:45-49.

13. Serafin M, Biasi MD, Franco V, Angerame D. In vitro comparison of cyclic fatigue resistance of two rotary single-file endodontic systems: OneCurve versus OneShape. Odontology 2019;107:196-201.

14. Bürklein S, Jager PG, SchäferE. Apical transportation and canal straightening with different continuously tapered rotary file systems in severely curved root canals: F6 SkyTaper and OneShape versus Mtwo. Int Endod J. 2017;50:983-990.

15. Ferreira F, Adeodato C, Barbosa I, Aboud L, Scelza $\mathrm{P}$, Scelza MZ. Movement kinematics and cyclic fatigue of NiTi rotary instruments: a systematic review. Int Endod J 2017;50:143-152.

16. De-Deus G, Moreira EJL, Lopes HP, Elias CN. Extended cyclic fatigue life of F2 ProTaper instruments used in reciprocating movement. Int Endod $\mathrm{J}$ 2010;43:1063-1068.

17. Burklein S, Hinschitza K, Dammaschke T, Schafer E. Shaping ability and cleaning effectiveness of two single-file systems in severely curved root canals of extracted teeth: Reciproc and WaveOne versus Mtwo and ProTaper. Int Endod J 2012;45:449-461.

18. Sen OG, Bilgin B, Kocak S, Saglam BC, Kocak MM. Evaluation of apically extruded debris using continuous rotation, reciprocation or adaptive motion. Braz Dent J 2018;29:245-248.

19. Celik G, Maden M, Savgat A, Orhan H. Shaping ability of Profile 25/0.06 and protaper F2 in rotary motion and reciproc in simulated canals. PeerJ 2018;6:e6109.

20. Shen Y, Qian W, Abtin H, Gao Y, Haapaalo M. Fatigue testing of controlled memory wire nickel titanium rotary instruments. J Endod 2011;37:997-1001. 21. Yang G, Wu H, Zheng Y, Zhang H, Li H, Zhou X. Scanning electron microscopic evaluation of debris and smear layer remaining following use of ProTaper and Hero Shaper instruments in combination with $\mathrm{NaOCl}$ and EDTA irrigation. Oral Surg Oral Med Oral Pathol Oral Radiol Endod 2008;106:e63-e71.

22. Foschi F, Nucci C, Montebugnoli L, Marchionni S, Breschi L, Malagnino VA, Prati C. SEM evaluation of canal wall dentine following use of Mtwo and ProTaper NiTi rotary instruments. Int Endod J 2004;37:832-839.

23. Schneider SW. A comparison of canal preparations in straight and curved root canals. Oral Surg Oral Med Oral Pathol 1971;32:271-275. 
24. Gorduysus M, Kucukkaya S, Bayramgil NP, Gorduysus MO. Evaluation of the effects of two novel irrigants on intraradicular dentine erosion, debris and smear layer removal. Restor Dent Endod 2015;40:216222.

25. Hulsmann M, Rummelin C, Schafers F. Root canal cleanliness after preparation with different endodontic handpieces and hand instruments: A comparative SEM investigation. Journal of Endodontics 1997;23:301-306.

26. American Association of Endodontics (2015) Glossary Contemporary Terminology for Endodontics. Available from: https://www.aae.org/specialty/clinicalresources/glossary-endodontic-terms/ [Accessed on 29 Mar 2019].

27. Jeevanandan G, Govindaraju L. Clinical comparison of Kedo-S paediatric rotary files vs manual instrumentation for root canal preparation in primary molars: a double blinded randomised clinical trial. Eur Arch Paediatr Dent 2018;19:273-278.

28. Kurthukoti AJ, Sharma P, Swamy DF, Shashidara R, Swamy EB. Computed Tomographic Morphometry of the Internal Anatomy of Mandibular Second Primary Molars. Int J Clin Pediatr Dent 2015;8:202-207.

29. Jeevanandan G, Thomas E. Volumetric analysis of hand, reciprocating and rotary instrumentation techniques in primary molars using spiral computed tomography: An in vitro comparative study. Eur J Dent 2018;12:21-26.

30. Hulsmann M, Peters OA, Dummer PMH. Mechanical preparation of root canals: shaping goals, techniques and means. Endod Topics 2005;10: 30-76.

31. Schafer E, Erler M, Dammaschke T. Comparative study on the shaping ability and cleaning efficiency of rotary Mtwo instruments. Part 2. Cleaning effectiveness and shaping ability in severely curved root canals of extracted teeth. Int Endod J 2006;39:203-212.

32. Govindaraju L, Jeevanandan G, Subramanian EMG. Clinical Evaluation of Quality of Obturation and
Instrumentation Time using Two Modified Rotary File Systems with Manual Instrumentation in Primary Teeth. J Clin Diagn Res 2017;11:55-58.

33. Saber SE, Nagy MM, Schafer E. Comparative evaluation of the shaping ability of WaveOne, Reciproc and OneShape single-file systems in severely curved root canals of extracted teeth. Int Endod J 2015;48:109114.

34. Lost C. Quality guidelines for endodontic treatment: consensus report of the European Society of Endodontology. Int Endod J 2006;39:921-930.

35. Kansal R, Rajput A. Comparison of Root Canal Cleaning Ability of Rotary and Reciprocating File Techniques: A SEM Study. JSM Dent Surg 2018;3:1030-1035.

36. Hema BS, Chandu GS, Shiraguppi VL. Scanning Electron Microscopic Evaluation of Root Canal Surfaces Prepared with LightSpeed \& Endowave Rotary System. J Clin Diagn Res 2014;8:35-38.

37. Celik D, Tasdemir T, Er K. Comparison of influence of different manufacturing methods on the cleaning efficiency of rotary nickeltitanium files. Microsc Res Techniq 2013;76:231-236.

38. Sharma G, Kakkar P, Vats A. A Comparative SEM Investigation of Smear Layer Remaining on Dentinal Walls by Three Rotary NiTi Files with Different Cross Sectional Designs in Moderately Curved Canals. J Clin Diagn Res 2015;9: 43-47.

39. Li H, Zhang C, Li Q, Wang C, Song Y. Comparison of cleaning efficiency and deformation characteristics of Twisted File and ProTaper rotary instruments. Eur J Dent 2014;8:191-196.

40. Robinson JR, Lumley PJ, Cooper PR, Grover LM, Walmsley AD. Reciprocating Root Canal Technique Induces Greater Debris Accumulation Than a Continuous Rotary Technique as Assessed by 3Dimensional Micro-Computed Tomography. J Endod 2013;39:1067-1070. 